\title{
Пластическая деформация - природа прямой фемтосекундной лазерной записи волноводов в кристаллах YAG
}

\author{
С.С. Федотов ${ }^{1}$, Л.Н. Бутвина ${ }^{2}, \underline{\text { А.Г. Охримчук }}^{1,2, *}$ \\ ${ }^{I}$ Российский Химико-Технологический Университет им. Д.И. Менделеева \\ ${ }^{2}$ Институт Общей Физики РАН им. А.М. Прохорова, НЦВО им. Е.М. Дианова. \\ *E-mail: okhrim@fo.gpi.ru
}

DOI: 10.31868/RFL2020.32-33

Прямая лазерная запись (direct laser writing) в объёме различных оптических сред зарекомендовала себя как гибкая и эффективная технология формирования волноводов и волноводных цепей в трёх-мерном формате. Этот метод позволяет структурировать показатель преломления среды с микронным и субмикронным разрешением. Механизм и природа изменения показателя преломления в стёклах и полимерах в основном понятны. Напротив, природа изменения показателя преломления в кристаллах при записи волноводов с низкими потерями не раскрыта. Понятны лишь механизмы изменения показателя преломления при экстремальном воздействии ультракоротких лазерных импульсов на монокристалл - при формировании полостей и фазовой трансформации $[1,2]$. Но такие режимы не годятся для записи волноводов с низкими потерями. Между тем важно знать состояние вещества и механизмы, приводящие к умеренной модификации сверхкороткими импульсами, поскольку такое знание позволило бы улучшить однородность записываемых треков изменённого показателя преломления, составляющих волноводов, и, как следствие, уменьшить волноводные потери.

Предмет данных исследований - продольная однородность треков, записанных пучком фемтосекундного лазера, сфокусированным объективом с $\mathrm{NA}=0.65$ в кристалле YAG:Nd и кварцевом стекле, и статистика энергии лазерных импульсов, прошедших через образцы во время этой записи. Обнаруженные закономерности в измеренных зависимостях позволили нам сделать выводы о природе модификации для широких диапазонов скоростей сканирования образца относительно перетяжки лазерного пучка, и энергий лазерных импульсов, в том числе при небольшом превышении порога модификации, то есть при энергии записи волноводов с низкими потерями.

Измерения относительного стандартного отклонения нелинейного пропускания лазерных импульсов (ОСОП) и продольной неоднородности треков мы представили в зависимости от перекрытия импульсов $P=D /(f * V)$ (Рис.1), где $D$ - диаметр перетяжки лазерного пучка, $f$ - частота повторения импульсов, $V$ скорость сканирования образца относительно перетяжки (сканирование перпендикулярно пучку). Продольная неоднородность трека $\mathrm{R}$ в кристалле YAG:Nd была получена с помощью анализа Фурье фазового изображения области кристалла, содержащей трек. Фазовое изображение получено с помощью количественной фазовой микроскопии $(\mathrm{QPm})$. Во всех экспериментальных зависимостях для кристалла наблюдается ступенька в области перекрытий $\mathrm{P}=11$ 15 , и монотонное дальнейшее увеличение ОСОП и неоднородности R. Для кварцевого стекла ступенек не наблюдается. Более того, зарегистрировано небольшое уменьшение измеряемых параметров при перекрытии более 15. 
Мы считаем, что модификация кристалла под воздействием жёстко сфокусированных сверхкоротких импульсов - есть пластическая деформация в микрообъёме. Пластическая деформация сопровождается генерацией вакансий, их объединением в вакансионные диски, и наконец, рождением из них дислокаций. Уменьшение показателя преломления - результат уменьшения плотности кристалла при пластическом растяжении под воздействием давления, создающегося в области электронной лазерной плазмы. Уменьшение плотности обусловлено появлением вакансионных дисков и агломерацией дислокаций. Во время прямой лазерной записи мы различили три режима пластической деформации, которые характерны и для традиционной деформации при механическом нагружении макро- образцов. Первый режим $(\mathrm{P}<9)$ - генерация дислокаций скольжения, второй (Р>15) - упрочнение, при котором генерируются дислокации различных систем скольжения, и как следствие они препятствуют скольжению друг другу, третий режим (P=9-15) - промежуточный, в котором происходит самоорганизация в системе дислокация, проявляющаяся в периодической модуляции показателя преломления с шагом в 1,2 мкм [3]. Режим пластической деформации однозначно определяется двумя параметрами энергией импульса и перекрытием Р.
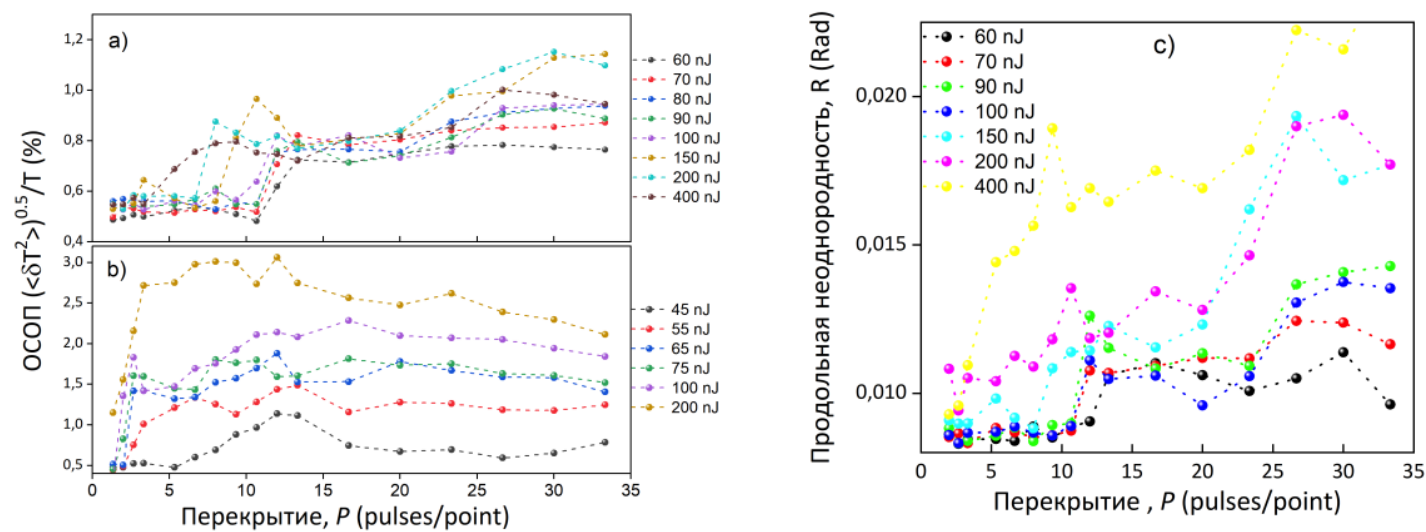

Рис.1. Зависимости ОСОП $(\mathrm{a}, \mathrm{b})$ и неоднородности треков для кристалла (a) кварцевого стекла (b).

Мы полагаем, что ступенька в зависимостях ОСОП и продольной неоднородности от перекрытия связана со сменой режима пластической деформации - от лёгкого скольжения дислокаций к упрочнению. Качественное различие измеренных зависимостей для кристалла и стекла мы объясняем фундаментально различной природой пластической деформации в кристаллах и стёклах. В кристаллах - это генерация и скольжение дислокаций, которые создают дальнодействующие поля напряжений, приводящие к взаимодействию и торможению движения дислокаций. В стёклах возможна перестройка только ближнего порядка, поэтому упрочнение не наблюдается.

Для записи волноводов с малыми потерями, следует обеспечить режим лёгкого скольжения дислокаций, то есть перекрытие импульсов в диапазоне 3-7. Мы ожидаем, что предложенная модель применима и к другим кристаллам, и открывает новый подход к исследованию природы прямой лазерной записи.

Исследования поддержаны РНФ, грант \#18-19-00733.

\section{Литература}

[1] E. G. Gamaly, S. Juodkazis, et al., Phys. Rev. B - Condens. Matter Mater. Phys. 73, 1-15 (2006).

[2] A.G. Okhrimchuk, A.S. Lipatiev, E.V. Zharikov et al., Opt. Mater. Express 7, 3408 (2017).

[3] D. Kuhlmann-Wilsdorf, Mater. Sci. Enginearing A 113, 1-41 (1989). 